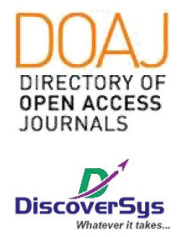

Published by DiscoverSys

\section{Karakteristik pasien cedera kepala di Rumah Sakit Umum Daerah (RSUD) Umbu Rara Meha Waingapu periode 1 Januari 2017 - 31 Desember 2018}

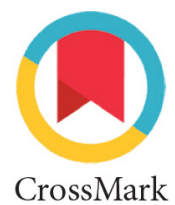

\author{
Made Bhuwana Putra
}

Keywords: characteristic, brain injury, RSUD Umbu Rara Meha, period

Cite This Article: Putra, M.B. 2019. AKarakteristik pasien cedera kepala di Rumah Sakit Umum Daerah (RSUD) Umbu Rara Meha Waingapu periode 1 Januari 2017 - 31 Desember 2018. Intisari Sains Medis 10 (2): 511-515. D0I: 10.15562/ism.v10i2.435
Dokter Magang, Rumah Sakit Umum Daerah (RSUD) Umbu Rara Meha, Waingapu, Sumba Timur, NTT, Indonesia

\section{Korespondensi:}

Made Bhuwana Putra; Dokter Magang, Rumah Sakit Umum Daerah (RSUD) Umbu Rara Meha, Waingapu, Sumba Timur, NTT, Indonesia; madebhuwana@gmail.com

Diterima : 13-03-2019

Disetujui : 28-07-2019

Diterbitkan : 01-08-2019

\title{
ABSTRAK
}

Pendahuluan: Cedera otak merupakan salah satu penyebab mortalitas dan morbiditas tertinggi di dunia, dengan prevalensi yang meningkat setiap tahunnya, hal ini terutama terjadi pada negara berkembang seiring dengan meningkatnya penggunaan kendaraan bermotor. Di Indonesia, meskipun angka kejadiannya tinggi, data mengenai kejadian serta karakteristik kasus - kasus pasien dengan cedera kepala masih terbatas. Studi ini bertujuan untuk menggambarkan pola karakteristik kasus cedera kepala di RSUD Umbu Rara Meha yang dapat merepresentasikan daerah Sumba.

Metode: Penelitian ini adalah penelitian deskriptif dengan desain penelitian retrospektif menggunakan data sekunder rekam medis yang dilakukan di RSUD Umbu Rara Meha Waingapu pada periode 1 Januari 2017 - 31 Desember 2018. Teknik non-probability sampling menggunakan metode konsekutif dilakukan. Data dianalisis menggunakan SPSS versi 25 dan ditampilkan dalam nilai rerata, in mean, median, frequency, and percentage.

Result: A total of 186 cases was included and from there it is shown that the highest prevalence rate of traumatic brain injury was in males $(67,7 \%)$, and was dominated by the adolescence group $(25,3 \%)$, although by occupation the highest rate was farmer and fisherman (32,3\%). The leading cause of traumatic brain injury is an accident $(82,2 \%)$ with mild traumatic brain injury $(67,7 \%)$ as the most frequent type of severity. The average length of stay for traumatic brain injury was two days.

Conclusion: The high number of the incidence rate of traumatic brain injury mainly from the accident and on adolescence group can be used as a reference for the local government or related institution to look more carefully about the awareness of safe driving or riding among the society and can be implemented through a program or other governing instrument. 


\section{PENDAHULUAN}

Cedera otak adalah suatu proses intrakranial yang disebabkan oleh benturan eksternal pada kepala. Benturan yang terjadi akan menyebabkan cedera pada otak apabila daya yang ditimbulkan melebihi kapasitas protektif otak., ${ }^{1,2}$ Cedera otak merupakan salah satu penyebab mortalitas dan morbiditas tertinggi di dunia, dengan prevalensi yang meningkat setiap tahunnya, hal ini terutama terjadi pada negara berkembang seiring dengan meningkatnya penggunaan kendaraan bermotor. ${ }^{2-4}$

Menurut data Riskerdas sendiri, di Indonesia terjadi peningkatan prevalensi kejadian cedera dengan penyebab tertinggi $(40,6 \%)$ adalah kecelakaan sepeda motor. ${ }^{5}$ Secara khusus daerah Nusa Tenggara Timur menempati angka tertinggi dalam proporsi cedera akibat terjatuh $(55,5 \%) .{ }^{5}$

Meskipun angka kejadiannya tinggi, data mengenai kejadian serta karakteristik kasus kasus pasien dengan cedera kepala masih minim khususnya pada daerah Sumba. RSUD Umbu Rara Meha merupakan rumah sakit di kota Waingapu, Sumba Timur, Provinsi NTT, dan merupakan rumah sakit terbesar di pulau Sumba. Saat ini merupakan rumah sakit rujukan untuk daerah Sumba, sehingga dinilai cukup representatif dalam memberikan gambaran mengenai kasus cedera kepala secara keseluruhan pada daerah ini.

Penelitian ini dilaksanakan dengan harapan dapat memberikan gambaran utuh mengenai kejadian cedera kepala sehingga dapat menjadi data dasar yang dapat dimanfaatkan dalam lingkup rumah sakit, dasar bagi penelitian selanjutnya, serta bagi pemerintahan daerah dalam mengimplementasikan kebijakan.

\section{METODE PENELITIAN}

\section{Rancangan dan Populasi Penelitian}

Penelitian ini adalah penelitian deskriptif dengan desain penelitian retrospektif menggunakan data sekunder rekam medis yang dilakukan di RSUD Umbu Rara Meha Waingapu pada periode 1 Januari 2017 - 31 Desember 2018. Populasi penelitian ini adalah seluruh pasien kasus cedera kepala di RSUD Umbu Rara Meha Waingapu.

\section{Sampel Penelitian}

Pengambilan sampel pada penelitian ini menggunakan teknik non-probability sampling dengan mengikutsertakan seluruh pasien cedera kepala di RSUD Umbu Rara Meha Waingapu pada rentang waktu 1 Januari 2017 - 31 Desember 2018 yang memenuhi kriteria inklusi yaitu pasien yang menderita cedera kepala yang dirawat inap di RSUD Umbu Rara Meha Waingapu bulan Januari
2017 sampai Desember 2018 dan usia subjek penelitian di atas 5 tahun. Kriteria ekslusi pada penelitian ini adalah pasien dengan data rekam medis yang tidak lengkap.

\section{Analisis Data}

Pada penelitian ini dilakukan analisa deskriptif dengan meliputi jenis kelamin, usia, pekerjaan, penyebab cedera kepala, jenis cedera kepala, tingkat keparahan cedera kepala, lama rawat inap dan keadaan saat pulang. Selanjutnya pengolahan data dilakukan dengan menggunakan piranti lunak SPSS versi 25.

\section{HASIL PENELITIAN}

Penelitian ini dilakukan dengan melihat dan mengumpulkan data rekam medik pasien penderita cedera kepala bulan Januari 2017 sampai bulan Desember 2018 berdasarkan data yang diteliti. Jumlah penderita cedera kepala pada penelitian ini berjumlah 190 orang dan 186 orang di antaranya memenuhi kriteria inklusi. Distribusi kasus cedera kepala berdasarkan jenis kelamin dapat dilihat pada Tabel 1. Penderita cedera kepala dengan jenis kelamin laki-laki berjumlah 126 orang $(67,7 \%)$ dan penderita cedera kepala dengan jenis kelamin perempuan berjumlah 60 orang $(32,3 \%)$.

Tabel 1 juga menunjukkan hasil bahwa penderita cedera kepala berdasarkan usia yaitu remaja akhir paling banyak berusia antara 17-25 tahun berjumlah 47 orang $(25,3 \%)$, anak berusia antara 5-11 tahun berjumlah 17 orang (9,1\%), remaja awal berusia antara 12-16 tahun berjumlah 19 orang $(10,2 \%)$, dewasa awal berusia antara 26-35 tahun berjumlah 33 orang $(17,7 \%)$, dewasa akhir berusia antara 36-45 tahun berjumlah 26 orang (14,0\%), lansia awal berusia antara 46-55 tahun berjumlah 25 orang $(13,4 \%)$, lansia akhir berusia antara 56-65 tahun berjumlah 18 orang $(9,7 \%)$, manula berusia lebih dari 65 tahun berjumlah 1 orang $(0,5 \%)$.

Selain itu, Tabel 1 juga menunjukan bahwa penderita cedera kepala paling banyak bekerja sebagai pelajar/mahasiswa berjumlah 52 orang $(28,0 \%)$, pegawai negeri berjumlah 17 orang $(9,1 \%)$, pegawai swasta berjumlah 7 orang $(3,8 \%)$, wiraswasta berjumlah 10 orang $(5,3 \%)$, honorer berjumlah 7 orang $(3,8 \%)$, pensiunan berjumlah 2 orang $(1,1 \%)$, petani/nelayan berjumlah 60 orang $(32,3 \%)$, ibu rumah tangga berjumlah 14 orang $(7,5 \%)$, dan tidak bekerja berjumlah 13 orang $(7,0 \%)$.

Sedangkan berdasarkan penyebabnya, penderita cedera kepala paling banyak disebabkan oleh kecelakaan lalu lintas berjumlah 153 orang $(82,2 \%)$, cedera kepala yang disebabkan oleh jatuh berjumlah 21 orang $(11,3 \%)$, cedera kepala yang disebabnkan 
Tabel 1. Distribusi penderita cedera kepala berdasarkan jenis kelamin, usia, pekerjaan, dan penyebab KLL

\begin{tabular}{lcc}
\hline \multicolumn{1}{c}{ Variabel } & $\begin{array}{c}\text { Frekuensi } \\
\text { (n=186) }\end{array}$ & $\begin{array}{c}\text { Persentase } \\
\text { (\%) }\end{array}$ \\
\hline Jenis Kelamin & & \\
Laki-laki & 126 & 67,7 \\
Perempuan & 60 & 32,3 \\
Usia & & \\
Anak (5-11) & 17 & 9,1 \\
Remaja Awal (12-16) & 19 & 10,2 \\
Remaja Akhir (17-25) & 47 & 25,3 \\
Dewasa Awal (26-35) & 33 & 17,7 \\
Dewasa Akhir (36-45) & 26 & 14,0 \\
Lansia Awal (46-55) & 25 & 13,4 \\
Lansia Akhir (56-65) & 18 & 9,7 \\
Manula (>65) & 1 & 0,5 \\
Pekerjaan & & \\
Pelajar/ Mahasiswa & 52 & 28,0 \\
Pegawai Negeri & 17 & 9,1 \\
Pegawai Swasta & 7 & 3,8 \\
Wiraswasta & 10 & 5,3 \\
Honorer & 7 & 3,8 \\
Pensiunan & 2 & 1,1 \\
Petani/Nelayan & 60 & 32,3 \\
Ibu Rumah Tangga & 14 & 7,5 \\
Tidak Bekerja & 13 & 7,0 \\
Tidak Diketahui & 4 & 2,1 \\
Penyebab Kecelakaan Lalu & & \\
Lintas (KLL) & & \\
Jatuh & 615 & \\
Kekerasan & & \\
Kelalaian/ & & \\
Tidak Sengaja & & \\
\hline & & \\
\hline
\end{tabular}

oleh kekerasan berjumlah 6 orang (3,2\%), dan cedera kepala yang disebabkan oleh kelalaian/tidak disengaja berjumlah 6 orang $(3,2 \%)$ (Tabel 1$)$.

Tabel 2 menunjukan bahwa penderita cedera kepala mengalami jenis cedera kepala Superficial injury of the head berjumlah 1 orang $(0,5 \%)$ intracranial injury berjumlah 99 orang $(53,2 \%)$, dan other and unspecified injuries of head berjumlah 86 orang $(46,2 \%)$. Ada beberapa penderita cedera kepala yang mengalami 2 jenis cedera kepala. Sedangkan jenis cedera kepala open wound of head, dislocation, fracture of skull and facial bone, sprain, and strain of joins and ligament, injury of eye and orbit, injury of cranial nerves, crushing injury of head, traumatic amputation of part of head tidak ditemukan dalam penelitian ini.

Disamping itu, Tabel 2 juga memperlihatkan bahwa penderita cedera kepala dengan GCS ringan (13-15) berjumlah 126 orang (67,7\%), penderita cedera kepala dengan GCS sedang (912) berjumlah 35 orang $(18,8 \%)$, dan penderita cedera kepala dengan GCS berat $(<9)$ berjumlah 13 orang $(13,4 \%)$. Berdasarkan hasil tersebut, pada penelitian ini didapatkan median dari lama rawat inap penderita cedera kepala dengan GCS ringan adalah 2,00 (1,00-10,00) hari, diikuti dengan GCS cedera kepala sedang 3,00 (1,00-16,00) hari, dan GCS cedera kepala berat sebanyak 5,00 (1,0022,00) hari.

Dan yang terakhir, Tabel 2 memperlihatkan gambaran kondisi penderita cedera kepala pada saat pulang dari rumah sakit. Pasien yang pulang dalam keadaan berobat jalan berjumlah 178 orang $(95,7 \%)$, pasien yang pulang atas permintaan sendiri sebanyak 3 orang $(1,6 \%)$, penderita cedera kepala yang meninggal berjumlah 4 orang $(2,2 \%)$ (Tabel 2).

\section{PEMBAHASAN}

Cedera kepala dapat berdampak berat bagi individu yang mengalaminya, dimana cedera kepala dapat menyebabkan gangguan kognitif, sosial dan perilaku, hal ini menyebabkan cedera kepala menjadi beban tidak hanya beban kesehatan namun juga ekonomi maupun sosial di seluruh dunia. Hal ini terutama terjadi pada negara - negara berkembang. ${ }^{7,8}$

Dari hasil penelitian ini dapat dilihat bahwa kasus cedera kepala lebih banyak terjadi pada lakilaki. Hal ini seusai dengan penelitian lain yang mengatakan bahwa laki-laki berisiko lebih tinggi mengalami cedera kepala daripada perempuan., ${ }^{4,7}$ Hal ini berkaitan dengan aktivitas dan resiko pekerjaan yang dilakukan laki - laki yang berat lebih memungkinkan menyebabkan kejadian cedera kepala pada laki - laki.

Cedera kepala paling banyak diderita oleh kelompok usia remaja akhir berusia antara 17-25 tahun yaitu 47 orang $(25,3 \%)$ dan paling sedikit diderita oleh manula berusia $>65$ tahun yaitu 1 orang $(0,5 \%)$. Hal ini sejalan dengan penelitian dari Faul et al, dimana didapatkan angka tertinggi kejadian adalah pada tingkat usia remaja atau dewasa muda. ${ }^{9}$ Penelitian lain juga menyebutkan angka kejadian tertinggi cedera kepala adalah pada usia remaja. ${ }^{8,10}$ Hal dapat disebabkan oleh remaja yang masih dalam tahap aktif untuk melakukan hal baru serta kelalaian dalam berkendara.

Dilihat dari sisi pekerjaan, dari studi ini dapat disimpulkan penderita cedera kepala paling banyak diderita oleh petani/nelayan sebanyak 60 orang $(32,3 \%)$ disusul oleh pelajar/mahasiswa sebanyak 52 orang (28\%). Hal ini bertentangan dengan penelitian lain yang menemukan bahwa penderita 
Tabel 2. Distribusi pasien berdasarkan pada jenis cedera kepala, nilai GCS, lama rawat inap, dan keadaan saat pulang

\begin{tabular}{|c|c|c|c|}
\hline Variabel & $\begin{array}{c}\text { Frekuensi } \\
(n=186)\end{array}$ & $\begin{array}{c}\text { Persentase } \\
\text { (\%) }\end{array}$ & $\begin{array}{c}\text { Median } \\
\text { (Min-Max) }\end{array}$ \\
\hline \multicolumn{4}{|l|}{ Jenis Cedera Kepala } \\
\hline Superficial injury of head (S00) & 1 & 0,5 & \\
\hline Open wound of head (S01) & 0 & 0 & \\
\hline \multicolumn{4}{|l|}{ Fracture of skull and facial bone } \\
\hline$(\mathrm{S} 02)$ & 0 & 0 & \\
\hline \multicolumn{4}{|l|}{ Dislocation, sprain, and strain } \\
\hline \multicolumn{4}{|l|}{ of joins and } \\
\hline ligament (S03) & 0 & 0 & \\
\hline Injury of cranial nerves (S04) & 0 & 0 & \\
\hline Injury of eye and orbit (S05) & 0 & 0 & \\
\hline Intracranial injury (S06) & 99 & 53,2 & \\
\hline Crushing injury of head (S07) & 0 & 0 & \\
\hline \multicolumn{4}{|l|}{ Traumatic amputation of part of } \\
\hline head (S08) & 0 & 0 & \\
\hline \multicolumn{4}{|l|}{ Other and unspecified injuries of } \\
\hline head (S09) & 86 & 46,2 & \\
\hline \multicolumn{4}{|l|}{ Nilai GCS } \\
\hline Ringan (13 - 15) & 126 & 67,7 & \\
\hline Sedang $(9-12)$ & 35 & 18,8 & \\
\hline Berat $(<9)$ & 25 & 13,4 & \\
\hline \multicolumn{4}{|l|}{ Lama Rawat Inap (Hari) } \\
\hline CKR & 126 & 67,7 & $2,00(1,00-10,00)$ \\
\hline CKS & 35 & 18,8 & $3,00(1,00-16,00)$. \\
\hline $\mathrm{CKB}$ & 25 & 13,4 & $5,00(1,00-22,00)$. \\
\hline \multicolumn{4}{|l|}{ Keadaan Saat Pulang } \\
\hline Pulang berobat jalan & 178 & 95,7 & \\
\hline Pulang atas permintaan sendiri & 3 & 1,6 & \\
\hline Meninggal & 4 & 2,2 & \\
\hline Dirujuk & 1 & 0,5 & \\
\hline
\end{tabular}

cedera kepala terbanyak adalah pada pelajar/ mahasiswa. ${ }^{4}$ Hal ini dimungkinkan terjadi pada daerah tertentu dengan populasi pekerjaan petani/ nelayan yang cukup tinggi.

Menilai dari penyebabnya didapatkan cedera kepala paling banyak disebabkan oleh kecelakaan lalu lintas yaitu 153 orang $(82,2 \%)$. Hal ini sesuai dengan penelitian lain yang menggambarkan angkat tertinggi penyebab cedera kepala adalah kecelakaan lalu lintas, terutama pada negara dengan pendapatan menengah ke bawah. ${ }^{7}$ Meskipun begitu hasil ini tidak sesuai dengan penelitian Faul et al. ${ }^{9}$ yang mengatakan bahwa jatuh adalah penyebab paling umum cedera kepala. Data Riskerdas sendiri menyebutkan daerah NTT merupakan tempat kejadian jatuh tertinggi di
Indonesia. ${ }^{5}$ Kecelakaan lalu lintas tidak hanya terkait masalah tabrakan antar kendaraan, namun lebih luas lagi seperti pejalan kaki yang ditabrak maupun kecelakaan tunggal. Khusus di daerah Waingapu sendiri cukup banyak terjadi kecelakaan melibatkan hewan seperti sapi, kuda dan lainnya.

Dari jenis cedera kepala berdasarkan ICD 10 dapat disimpulkan bahwa penderita cedera kepala paling banyak mengalami jenis cedera kepala intracranial injury yaitu 99 orang $(53,2 \%)$. Hal ini sama dengan hasil yang didapatkan oleh National Institute for Health and Care Excellence (NICE) yang mengatakan bahwa concussion adalah penyebab tersering cedera kepala. $^{10}$ Concussion sendiri merupakan bagian dari intacranial injury. Hal ini dapat disebabkan karena umumnya penderita cedera kepala datang ke pusat pelayanan kesehatan akibat gejala concussion.

Dilihat dari tingkat keparahannya, studi ini menunjukan bahwa penderita cedera kepala paling banyak adalah dalam kategori GCS cedera kepala ringan (13-15) yaitu 126 orang (67,7\%). Hal ini sejalan dengan penelitian oleh Li et al. bahwa penderita cedera kepala terbanyak memiliki nilai GCS cedera kepal ringan (13-15) dan GCS cedera kepala berat (3-8) adalah yang paling sedikit. ${ }^{4}$ Sedangkan untuk lama rawat inap pada masingmasing nilai GCS bergantung dari beberapa hal seperti beratnya diagnosa atau kondisi klinis atau gangguan penyerta dari penderita cedera kepala. Dan setiap penelitian mempunyai median lama rawat inap yang bervariasi diakrenakan jumlah dan karakteristik pasien yang juga berbeda.

Dapat dilihat pada studi ini bahwa keadaan penderita cedera kepala saat pulang paling banyak diperbolehkan pulang berobat jalan yaitu 178 orang $(95,7 \%)$. Hal ini juga bergantung dengan tingkat keparahan atau jenis cedera yang terjadi dan dapat berkaitan juga dengan distribusi tingkat keparahan dimana yang terbanyak adalah penderita cedera kepala ringan.

\section{KESIMPULAN}

Studi ini memperlihatkan tingginya prevalensi cedera kepala pada laki - laki dibandingkan perempuan dan didominasi oleh kelompok usia remaja akhir, meskipun dilihat dari pekerjaan yang terbanyak adalah pada petani atau nelayan. Penyebab terbanyak kasus ini adalah kecelakaan, dengan jenis intracranial injury. Cedera kepala ringan memiliki frekuensi tertinggi dibanding dengan tingkat keparahan cedera kepala lainnya, dengan rata - rata lama rawat inap 2 hari dan pasca perawatan di rumah sakit pasien umumnya diperbolehkan rawat jalan. 


\section{KETERBATASAN PENELITIAN}

Terdapat beberapa keterbatasan pada penelitian ini antara lain adalah pada sebagian besar rekam medis tidak tersedia informasi mengenai penggunaan alat pengaman diri seperti helm utamanya pada kasus kecelakaan yang dapat dikorelasikan dengan kondisi cedera kepala pada pasien sehingga dirasa perlu bagi RSUD Umbu Rara Meha Waingapu untuk menambahkan informasi tersebut pada setiap kasus cedera kepala yang kemudian dapat digunakan untuk penelitian selanjutnya.

Merujuk dari hasil penelitian ini, melihat tingginya prevalensi cedera kepala yang terutama adalah akibat kecelakaan dan pada kelompok usia remaja dapat menjadi pertimbangan bagi pemerintah daerah setempat untuk lebih memerhatikan kesadaran keamanan berkendara bagi masyarakat setempat baik melalui program atau instrumen lainnya.

\section{ETIKA PENELITIAN}

Penelitian ini telah mendapatkan persetujuan etik dari RSUD Umbu Raha Meha Waingapu sebelum studi di jalankan sebelumnya.

\section{KONFLIK KEPENTINGAN}

Tidak terdapat konflik kepentingan dalam penyusunan laporan hasil penelitian pada artikel ini

\section{PENDANAAN}

Penulis bertanggung jawab terhadap pendanaan studi ini tanpa melibatkan pihak sponsor, grant, ataupun berbagai sumber pendanaan lainnya.

\section{KONTRIBUSI PENULIS}

IMBP bertanggung jawab dalam penulisan artikel ini dari penyusunan kerangka penelitian, pengambilan sampel, hingga analisis data penelitian.

\section{DAFTAR PUSTAKA}

1. Lozano D, Portillo GS, Acosta S, et al. Neuroinflammatory responses to traumatic brain injury: etiology, clinical consequences, and therapeutic opportunities. Neuropsychiatric Dis Treat. 2015;11:97-106.

2. Kumar A, Loane DJ. Neuroinflammation after Traumatic Brain Injury: Opportunities for Therapeutic Intervention. Brain Behav Immun. 2012; 26(8):1191 - 1201.

3. Peeters W, van den Brande R, Polinder S, Brazinova A, Steyerberg EW, Lingsma HF, Maas AI. Epidemiology of traumatic brain injury in Europe. Acta Neurochir (Wien). 2015; 157(10):1683-1696.

4. Li M, Zhao Z, Yu G, Zhang J. Epidemiology of traumatic brain injury over the world: A systematic review. General Medicine: Open Access. 2016; 4(5):1-14.

5. Riset Kesehatan Dasar (Riskesdas). 2013. Badan Litbangkes, Depkes RI. Jakarta.

6. Morris S, Ridley S, Lecky FE, Munro V, Christensen MC. Determinants of hospital costs associated with traumatic brain injury in England and Wales. Anaesthesia. 2008;63(5):499-508.

7. MRC CRASH Trial Collaborators, Perel P, Arango M, Clayton T, Edwards P, Komolafe E, et al. Predicting outcome after traumatic brain injury: practical prognostic models based on large cohort of international patients. BMJ. 2008;336(7641):425-9.

8. Frieden TR, Houry D, Baldwin G. Traumatic brain injury in the United States: Epidemiology and rehabilitation. CDC and NIH Report to Congress. 2015; 1-74.

9. Faul M, Coronado V. Epidemiology of traumatic brain injury. Handb Clin Neurol. 2015;127:3-13.

10. Pandor A, Goodacre S, Harnan S, Holmes M, Pickering A, Fitzgerald P, Rees A, Stevenson M. Diagnostic management strategies for adults and children with minor head injury: a systematic review and an economic evaluation. Health Technol Assess. 2011;15(27):1-202.

11. National Institute for Health and Care Excellence (NICE). The early management of head injuries, UK. 2014.

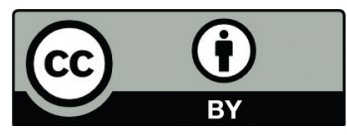

This work is licensed under a Creative Commons Attribution 